\title{
Biosynthesis of fluorescent silver nanoparticles from Leea coccinea leaves and their antibacterial potentialities against Xanthomonas phaseoli pv phaseoli
}

\author{
María del Carmen Travieso Novelles ${ }^{1 *} \mathbb{B}$, Annie Rubio Ortega ${ }^{1}$, Beatriz Alvarez Pita', Mylene Corzo López², \\ Lianet Díaz Pérez ${ }^{1}$, Emilio Acosta Medina ${ }^{3}$ and Oriela Pino Pérez
}

\begin{abstract}
The synthesis of silver nanoparticles (SNP) from plants is a simple, fast and environmentally safe route. In the present study, the aqueous extract of fresh leaves from Leea coccinea $\mathrm{L}$. was evaluated as a possible source of reducing and stabilizing agents to obtain SNP. The synthesized SNP were characterized by spectroscopic techniques such as UV-visible spectrophotometry and Fourier transform infrared spectroscopy (FTIR), scanning electron and confocal microscopies and the antimicrobial activity against Xanthomonas phaseoli pv. phaseoli was evaluated using agar diffusion methods. The results showed that the evaluated extract was promising for the green synthesis of the SNP, which was visually identified by the formation of a dark-brown complex and the presence of a peak of maximum absorption at $470 \mathrm{~nm}$ in a UV-VIS spectrum. FTIR spectrum of SNP showed main characteristic signals of aromatic compounds, carboxylic group among others confirmed by phytochemical screening that made evident the presence of flavonoids, phenols, leucoanthocyanidins, terpenes and steroids groups. Fluorescent SNP with high degree of agglomeration were observed by the microscopical technics used. A promising antibacterial activity of SNP was shown by a zone of microbial growth inhibition. These results suggested the need for going deeper in the physico-chemical characterization and kinetic studies, as well as the biological evaluations to make possible the use of this plant source in the future development of antibacterial formulations for bean seed protection.
\end{abstract}

Keywords: Leaves extract, Silver nanoparticles, Antibacterial properties, Xanthomonas

\section{Introduction}

Phytopathogenic bacteria cause a negative impact on agricultural production systems, decrease yields and increase economic losses (Pedroza et al. 2013). The genus Xanthomonas (Proteobacteria) is a diverse group of Gram-negative bacteria that affects numerous crops (Pedroza et al. 2013; Corzo et al. 2015). The disease known as common bacteriosis or common blight, widely

\footnotetext{
*Correspondence: mcarmen@censa.edu.cu

${ }^{1}$ Laboratory of Chemical-Ecology, National Center for Animal and Plant Health (CENSA), San José de las Lajas, Mayabeque, Cuba

Full list of author information is available at the end of the article
}

distributed in the world, is caused by Xanthomonas phaseoli pv. phaseoli (Smith) Vauterin and X. citri subsp. fuscans (Burkholder) Starr \& Burkholder (Corzo et al. 2015). This disease is the main biotic factor affecting the yields of Phaseolus vulgaris (common bean) causing losses in this crop of $10-40 \%$, depending on the cultivar susceptibility and environmental conditions (Pedroza et al. 2013; Corzo et al. 2015; Constantin et al. 2016; Francisco et al. 2013).

At present, management of this pest is complex and multifactorial, in which the seed control is essential. In this sense, efforts are made for searching resistant varieties (Rodríguez et al. 2015), biological and chemical 
controls (Aguilar et al. 2019; Ararsa et al. 2018) as a means to guarantee its quality. Numerous authors point out that the foliar application of copper-based bactericides, crop rotation, intercropping, among other actions, are successful if they are applied in an integrated management program (Ararsa et al. 2018). The use of chemical pesticides based on copper, either for the treatment of the seed or systemic treatment, is one of the most widespread alternatives to control this pest; however, numerous studies have shown the resistance of the bacteria (Ram et al. 2018).

In recent years, there has been an increase in research focused on developing nanotechnologies based on the potentialities of biological systems (microorganisms, algae, plants, etc.) to endogenous production or extracellular secretion of metabolites capable of, by different types of reactions (e.g., redox with metallic elements), form coordination complexes of particle sizes in the order of nanoscale, with potential applications in dissimilar fields, including agriculture (Rajesh et al. 2012; Shende et al. 2016). Plants are the most ancestral and fruitful source for obtaining active substances, however, many authors recognize the infinite arsenal of these botanical sources of which only a small fraction has been studied within the great diversity available globally (De Luca et al. 2012; Palhares et al. 2015; Newman and Cragg 2016; Rai et al. 2009). One aspect of pharmacognostic studies is the synthesis of biogenic nanoparticles from the reaction of phytochemical compounds present in extracts of plant parts with metal cations (e.g., $\mathrm{Ag}^{+}$) or other substances yielding nanoparticles (NPs) which in their structure contain the reduced metallic cation covalently bound to the phytochemical compounds or secondary metabolites (alkaloids, flavonoids, phenolic compounds, polysaccharides, vitamins, amino acids, terpenoids, etc.), which drastically change the physical-chemical properties (optical, electrical, magnetic, etc.) and biological effects of the metals and compounds involved (Rai et al. 2009) with important biological effects at cellular level (Kasithevar et al. 2017). The synthesis of silver nanoparticles (SNP) from plants represents an advantageous technological alternative due to its simplicity, low cost, the possibility of carrying out large-scale productions, as well as involving environmentally friendly processes to obtain a new generation of antimicrobial compounds (Kasithevar et al. 2017; Rao et al. 2016; Sarkar and Goutam 2017; Arokiyaraj et al. 2017; Singh et al. 2014; Sun et al. 2014; Rajathi and Sridhar 2013; Chandrappa et al. 2017; Ronavari et al. 2017; Sharma et al. 2015). Numerous botanical species have been reported for these purposes (Dhand et al. 2016; Suparna and Anantharaman 2017; Kumar et al. 2017; Ibraheem et al. 2016; Anandalakshmi and
Venugobal 2017; Algebaly et al. 2020; Travieso et al. 2018; Gupta and Chauhan 2017).

Leea coccinea is within the 70 species of the genus Leea belonging to Vitaceae family (before Leeaceae) (International Seed Testing Association 2013) and shows a wide global distribution (Australia, New Guinea, South and Southeast Asia, parts of Africa and the Americas). In Cuba, $L$. coccinea specie abounds in the western region and it is used primarily as a living fence and as an ornamental plant due to the beauty of its foliage and inflorescences. Although other species of the genus have been studied (Emran et al. 2012; Joshi et al. 2016; Mahmud et al. 2017; Halder et al. 2018), reports on the chemical composition of L. coccinea are hardly found in the literature reviewed. The antimicrobial activity of Leea species has been demonstrated (Joshi et al. 2016; Tun et al. 2019). Recent reports showed the antinociceptive and anthelmintic activity of Leea aequata leaf extracts (Halder et al. 2018). Other authors have justified the antioxidant and antibacterial potential of root tubers of Leea macrophylla which is a potential tool in the treatment of disorders associated with oxidative stress and pathogenic infections (Joshi et al. 2016; Mahmud et al. 2017).

The phytochemical screening of ethanolic extract of root tubers of Leea macrophylla revealed that it is rich in phenolic compounds (Joshi et al. 2016; Mahmud et al. 2017); saponins (Joshi et al. 2016). Also this extract is rich in carbohydrates between others phytochemical (alkaloids and flavonoids) of high biological value (Joshi et al. 2016).

The aims of the current study were to evaluate the aqueous extract of the Leea coccinea leaves, as a possible source of reducing and stabilizing agents for obtaining SNP, as well as to determine its potential as an antibacterial agent against $X$. phaseoli pv. phaseoli.

\section{Materials and methods Plant material}

Leaves of Leea coccinea plants, located at 22,990,173 N and $-82,151,213 \mathrm{~W}$ at a height of 142 masl (red point in Fig. 1), were collected and selected to remove soil contaminant. Their authentication was carried out by the specialist in botany from Agrarian University of Havana (UNAH), Mayabeque, Cuba.

\section{Preparation of plant extracts and biosynthesis of SNP}

The collected fresh leaves of $L$. coccinea, thoroughly checked for being free of any contaminant, were triturated to a thick powder. Then $5 \mathrm{~g}$ of the powder were macerated with deionized water $(1: 8)(\mathrm{W} / \mathrm{V})$. This mixture was heated to $90{ }^{\circ} \mathrm{C}$ for $10 \mathrm{~min}$, and after being cooled, filtered through Whatman No. 1 paper. 


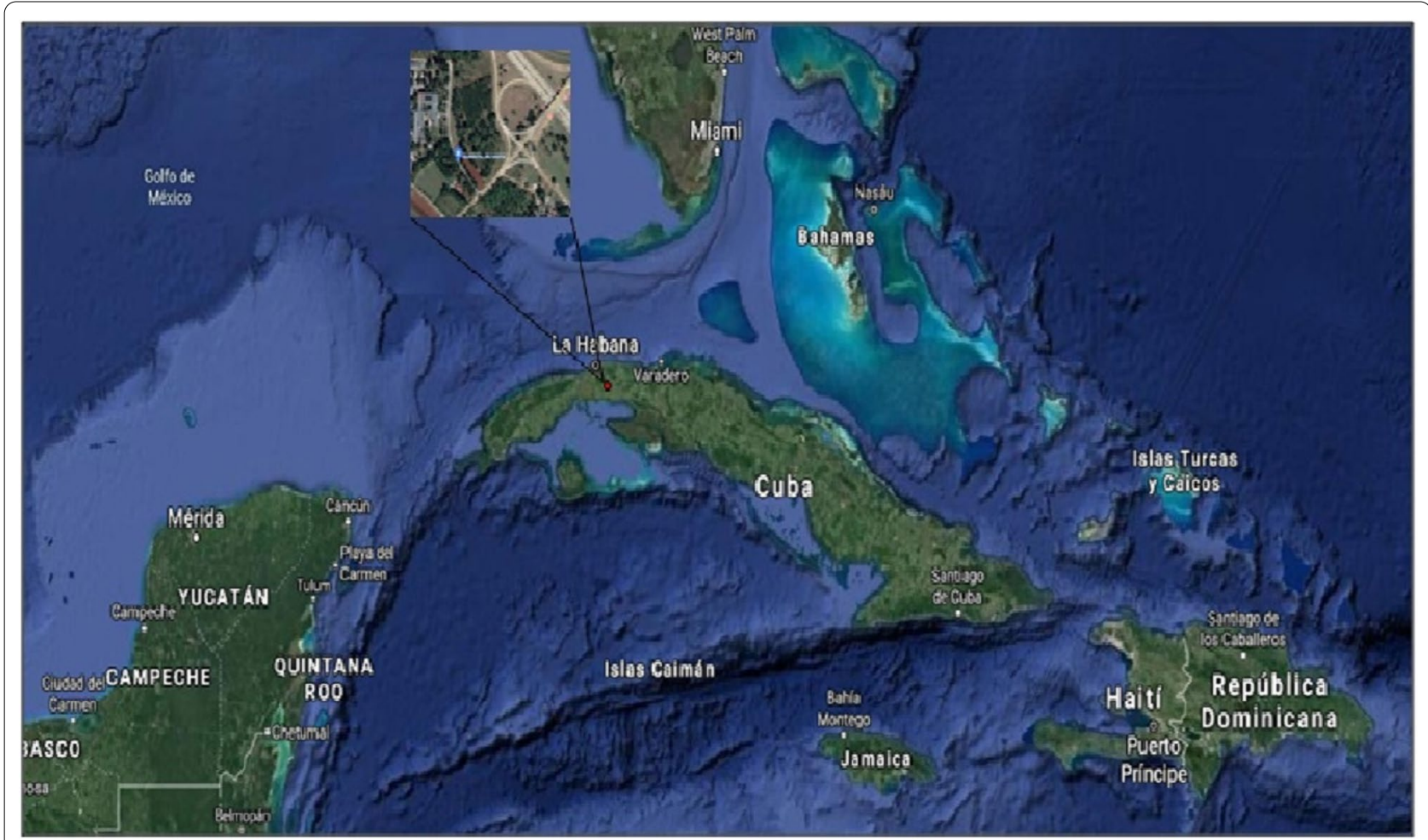

Fig. 1 Geo-localization of the plant material of Leea coccinea

SNP synthesis was carried out by a typical procedure (Fig. 2). The solution of silver nitrate $(2 \mathrm{mM})$ was added to the plant extract $(9: 1)(\mathrm{V} / \mathrm{V})$. It was homogenized with a mechanical stirrer (IKA-VF2) and left to rest for $24 \mathrm{~h}$ at room temperature $\left(27 \pm 2{ }^{\circ} \mathrm{C}\right)$. The bio-reduction reaction was monitored by visual observation at different times (5 min, $1 \mathrm{~h}$ and $24 \mathrm{~h}$ ). A change of color to dark brown was indicative of the formation of SNP. The resulting suspension of SNP was centrifuged at 10,000 rpm for $20 \mathrm{~min}$, and the pellet was washed with sterile water three times. SNP were stored at room temperature in the dark until evaluation. The yield of SNP was determined by measuring of the dry weight of $1 \mathrm{~mL}$ of the suspension for triplicate on an infrared balance (Sartorius MA35) and calculated with relation to the initial mass of plant material. The results were expressed as the media valor in the range of the standard deviation.

\section{Characterization of SNP}

The biosynthesized SNP were characterized by various instrumental analyses. The $\mathrm{pH}$ of the aqueous suspension of nanoparticles was determined at different times $(5,10,30,60,90$ and $120 \mathrm{~min})$ by a Mettler Toledo instrument. The formation of SNP was demonstrated by UV-VIS spectrum (300-800 $\mathrm{nm}$ ) through RAYLEIGH (VIS-723G) spectrophotometer and the spectrum of
Fourier transform infrared spectroscopy (FTIR) in the range $4500-200 \mathrm{~nm}$ by using an IR Prestige 21 equipment (SHIMADZU). The scanning electron microscopic (SEM) analysis was performed using the MIRA 3 LMU (TESCAN) SEM machine. Samples to SEM analysis were applied on carbon adhesive films and coated with gold $(5 \mathrm{~nm})$ with a Desk Sputter Coater DSR1. The films were dried during $24 \mathrm{~h}$. The EDX analysis of SNP was carried out on samples using Energy Disperse Ray X (Oxford Instrument). Fluorescence properties were demonstrated with confocal microscopy (FICT-wide $479 \mathrm{~nm}$ Lent $20 \times$ ). It was performed on samples previously sonicated for $10 \mathrm{~min}$ and applied on porous albumin slides covered with coverslips, which were kept in a humid chamber until observation.

Phytochemical screening of aqueous extract of leaves of L. coccinea was done to identify the presence of secondary metabolites with reducing properties. Several qualitative tests included in the internal protocol established in the Chemical- Ecology Laboratory, and classics reactions such as ninhydrin (free amino acids), ferric chloride (phenols), gelatin (phenols), Liebermann-Burchard (triterpenes and steroids), Kedde (lactonic rings), Borntrager (quinone), Shinoda (flavonoids), Rosenheim (leucoanthocyanidins) and Mayer-Dragendorff-Hager-Wagner to alkaloids, were carried out. 

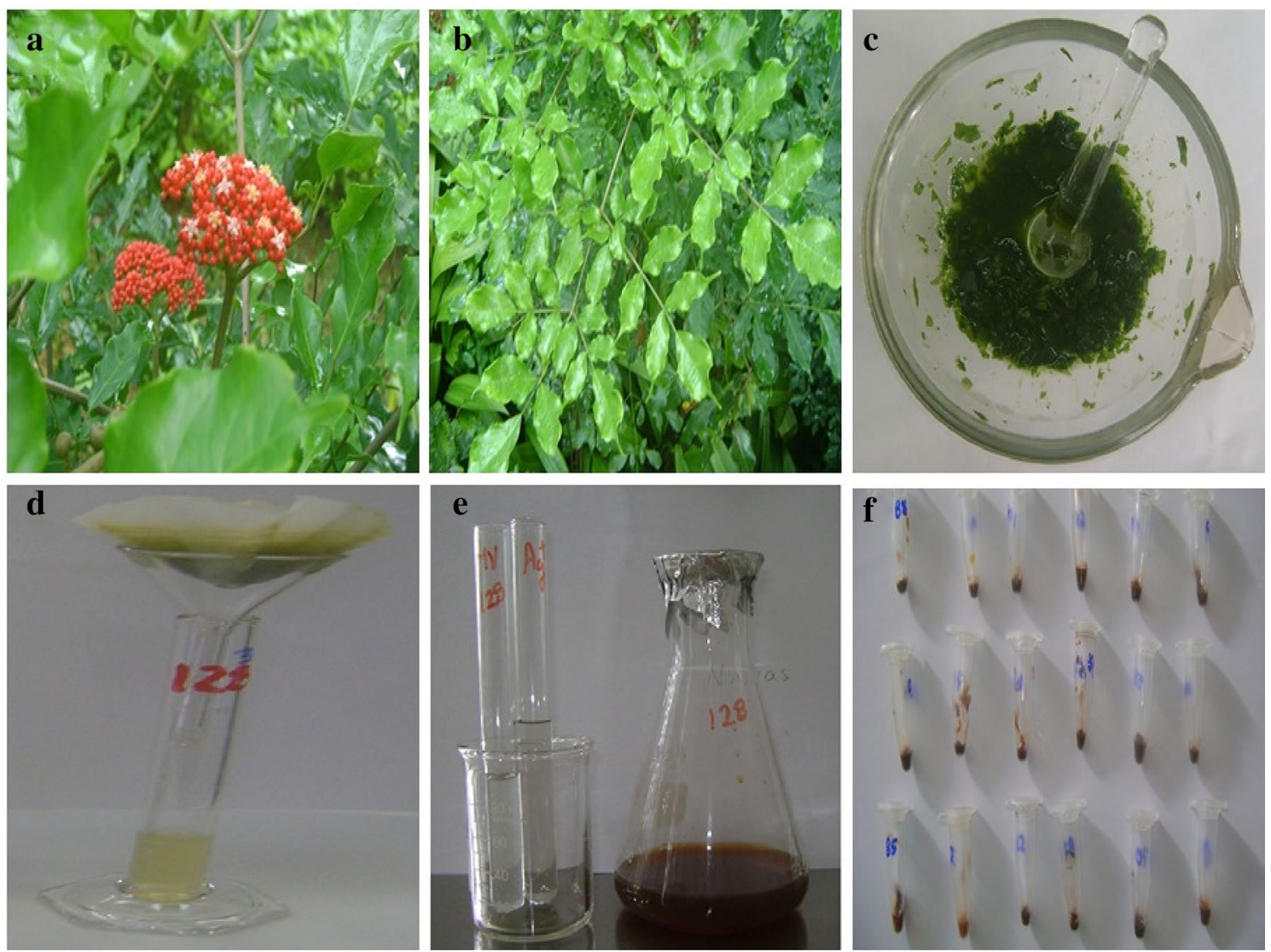

Fig. 2 Biosynthesis of SNP from Leea coccinea ( $L C$ ) leaves. a Shrubs of $L C$ with flowers; b leaves of $L c$; c maceration; d filtration; e reaction of bio-reduction con $\mathrm{Ag}^{+} ; \mathbf{f}$ precipitation

\section{Evaluation of antimicrobial activity}

To evaluate the antimicrobial activity of SNP, the colloidal suspension was precipitated by centrifugation $(10,000 \mathrm{rpm}$ for $20 \mathrm{~min})$ to remove excess of salt and others soluble compounds. The silver colloids were washed at least three times with deionized water. The antibacterial activity on Xanthomonas phaseoli pv. phaseoli was evaluated by the disk agar diffusion method (Clinical and Laboratory d Institute 2015). An inoculum was prepared at the concentration of $29 \times 10^{7} \mathrm{UFC} \mathrm{mL} \mathrm{m}^{-1}$, in sodium chloride solution $(0.9 \%)$, from a culture of 24 -h incubation at the temperature of $28{ }^{\circ} \mathrm{C}$ in nutrient agar plates, according to the McFarland scale. The strain used was Xap1, belonging to the ceparium of the Laboratory of Plant Bacteriology of the National Center for animal and Plant Health in Cuba (Corzo et al. 2015). For application on disks, $10 \mu \mathrm{L}$ of the precipitated SNP was applied in every disk. As positive controls, erythromycin $(5 \mu \mathrm{g})$ and CHLORAMPHENICOL $(10 \mu \mathrm{g})$ disks were applied. Sterile water was used as a negative control. At least four replications of the treatment and controls were performed. Plates were incubated at $28{ }^{\circ} \mathrm{C}$ for $24 \mathrm{~h}$. After this time, zone of inhibition $(\mathrm{mm})$ of bacterial growth were measured with a graduated rule.

The data obtained were statistically processed by a simple variance analysis and the means were compared using the Duncan multiple range comparison test with a significance level of 5\%, using the statistical package InfoStat/ L (Di Rienzo et al. 2016).

\section{Results and discussion}

The reaction of bio-reduction between the $\mathrm{Ag}^{+}$cations and the phytochemical compounds of the aqueous extract of $L$. coccinea leaves occurred instantaneously (before $5 \mathrm{~min}$ ), made evident by the presence of a darkbrown colored complex (Fig. 3a), indicative of the formation of nanoparticles (Vadlapudi and Amanchy 2017; Sarkar and Goutam 2017; Khan et al. 2018). UV-visible spectroscopic absorbance (Fig. 3b) showed a signal with $\lambda_{\max }$ around of $470 \mathrm{~nm}$ due to strong surface plasmon resonance, which reaffirms the formation of SNP (Travieso et al. 2018). The release of $\mathrm{H}^{+}$ions since the first minutes of the reaction was verified by the gradual decrease of the aqueous medium pH (Fig. 3c). Some authors have 

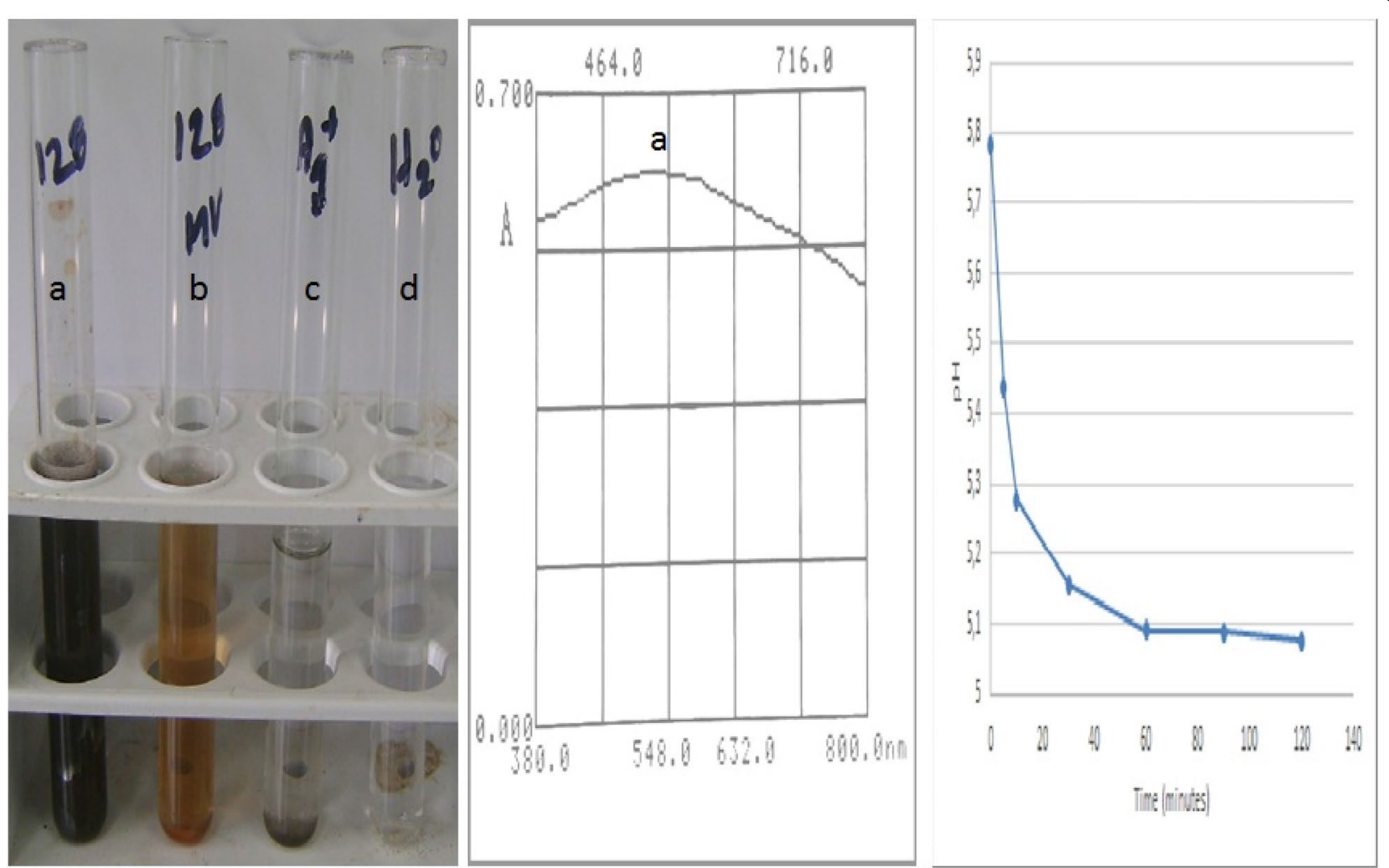

Fig. 3 Identification of the formation of SNP from Leea coccinea. Visual (a), spectrophotometric (b) and pH variation during bio-reduction (c). a: positive reaction between aqueous extract of leaves (AEL): silver solution $2 \mathrm{mM}(1: 9)(V / N)$; b: negative reaction of AEL: distilled water (1:9); c: silver solution 2 mM: distilled water (9:1); d: distilled water

explained the oxidation process of $\mathrm{Ag}^{+}$by phytochemical compounds from plants, which are accompanied by the release of $\mathrm{H}^{+}$ions (Zuorro et al. 2019). Also, it has been proposed that tautomer transformations of other compounds from plants (e.g., flavonoids) from the enol form into the keto form can release reactive hydrogen atoms that reduce metal ions to coordination complex of $\mathrm{Ag}$ forming nanoparticles. Nevertheless, due to the complex composition of natural extracts, up to now, there is not enough evidence about which specific phytochemicals are responsible for the formation of nanoparticles (Jeevanandam et al. 2016).

FTIR spectrum confirmed the phytochemicals screening (Fig. 4). Measurements were carried out to identify the functional groups responsible for the reduction of the $\mathrm{Ag}^{+}$ions and capping of the bio-reduced silver nanoparticles synthesized by $L$. coccinea leaf extract. FTIR spectrum of SNP showed the presence of signals such as strong peaks between 3083 and $3076 \mathrm{~cm}^{-1}$ (peak 8) with a signal at $1538 \mathrm{~cm}^{-1}$ (peak 16) like aromatic with multiple substitutions $(\mathrm{C}=\mathrm{C}$ stretching); other peaks were around $1616 \mathrm{~cm}^{-1}$ (peak 15) ( $\mathrm{C}=\mathrm{O}$ stretching) of carboxylic group. The absorption at about $1334 \mathrm{~cm}^{-1}$ (peak

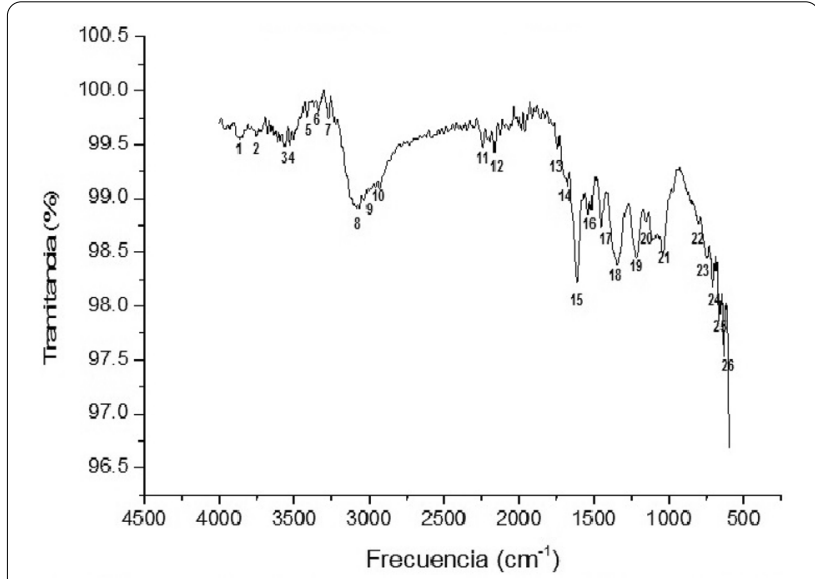

Fig. 4 FTIR spectra of SNP synthesized of $L$. coccinea leaf extract. Main peaks: $8(16,18)(22-26)$ : aromatic (benzene with substitutions); 15(19): $-\mathrm{COOH}$ carboxylic $(\mathrm{C}=\mathrm{O}) ; 17(10): \mathrm{C}=\mathrm{H}$ (methylene)

18) indicates a residual amount of $\left(\mathrm{NO}_{3}\right)^{-1}$ ion in the solution. Others signals appear at $1207 \mathrm{~cm}^{-1}$ (peak 19), between 3881 and $3831 \mathrm{~cm}^{-1}$ (peak 1), $3752 \mathrm{~cm}^{-1}$ (peak 2), $3565 \mathrm{~cm}^{-1}$ (peak 3), $3529 \mathrm{~cm}^{-1}$ (peak 4), between 
3414 and $3335 \mathrm{~cm}^{-1}$ (peak 6) suggesting polyphenolic $\mathrm{OH}$ group along with the peak around $880 \mathrm{~cm}^{-1}$ which represents the aromatic ring $\mathrm{C}-\mathrm{H}$ vibrations. Others peaks around of $3270 \mathrm{~cm}^{-1}$ (peak 7), $3025 \mathrm{~cm}^{-1}$ (peak 9), between 2932 and $2925 \mathrm{~cm}^{-1}$ (peak 10), $2235 \mathrm{~cm}^{-1}$ (peak 11), $2171 \mathrm{~cm}^{-1}$ (peak 12), $1747 \mathrm{~cm}^{-1}$ (peak 13), $1688 \mathrm{~cm}^{-1}$ (peak 14), $1451 \mathrm{~cm}^{-1}$ (peak 17), $1156 \mathrm{~cm}^{-1}$ (peak 20) and between 1107 and $1035 \mathrm{~cm}^{-1}$ (peak 21) indicating the complexity of samples containing nanoparticles from natural sources and suggesting the need for continuous studies about the chemical structures of compounds involved in bio-reduction.

The SEM images (Fig. 5a, b) of SNP showed the presence of abundant nanoparticles with high grade of aggregation which was confirmed with confocal microscopy images, where the emitted fluorescence was detected at $479 \mathrm{~nm}$, demonstrating the occurrence of overlapping of smaller particles (Fig. 5c). Numerous authors have reported an agglomeration due to strong electrostatic interactions of metal ions. The fluorescent properties suggest the presence of phytoconstituents or antioxidants with fluorophore groups. Others metal nanoparticles synthesized from plants have been reported with fluorescent properties (Talamond et al. 2015; Donaldson and Williams 2018).
The results of the qualitative analysis by EDX (Fig. 6) showed a high percentage of $\mathrm{Ag}$ made evident by the strong signals in the range of $2-4 \mathrm{keV}$, as well as the presence of carbon and oxygen indicative of hybrid NPs, with an organic component (e.g., flavonoid) covalently bound to the metallic element. Likewise, the high compaction shows its crystalline nature due to the reduction of $\mathrm{Ag}^{+}$cations by the reducing compounds present in the aqueous extract of $L$. coccinea leaves (Singh et al. 2019; Kasithevar et al. 2017; Moodley et al. 2018; Oluwasogo et al. 2019).

Phytochemical screening showed the presence of secondary metabolites such as phenols, triterpenes and steroids, flavonoids, free amino acids and leucoanthocyanidin in the aqueous extract of leaves of Leea coccinea (Table 1). Some of these compounds could react with $\mathrm{Ag}^{+}$to form coordination complexes, so that, due to the presence of several functional groups with reducing properties, kinetic and chemical studies should be carrying out to enlighten the reaction of bio-reduction. At present, very few reports are available on $L$. coccinea phytochemistry. Previous studies on chemical compositions of others species of the genus Leea are in agreement with our previous results. Flavonoids and flavonoid glycosides are found to be the major constituents of the

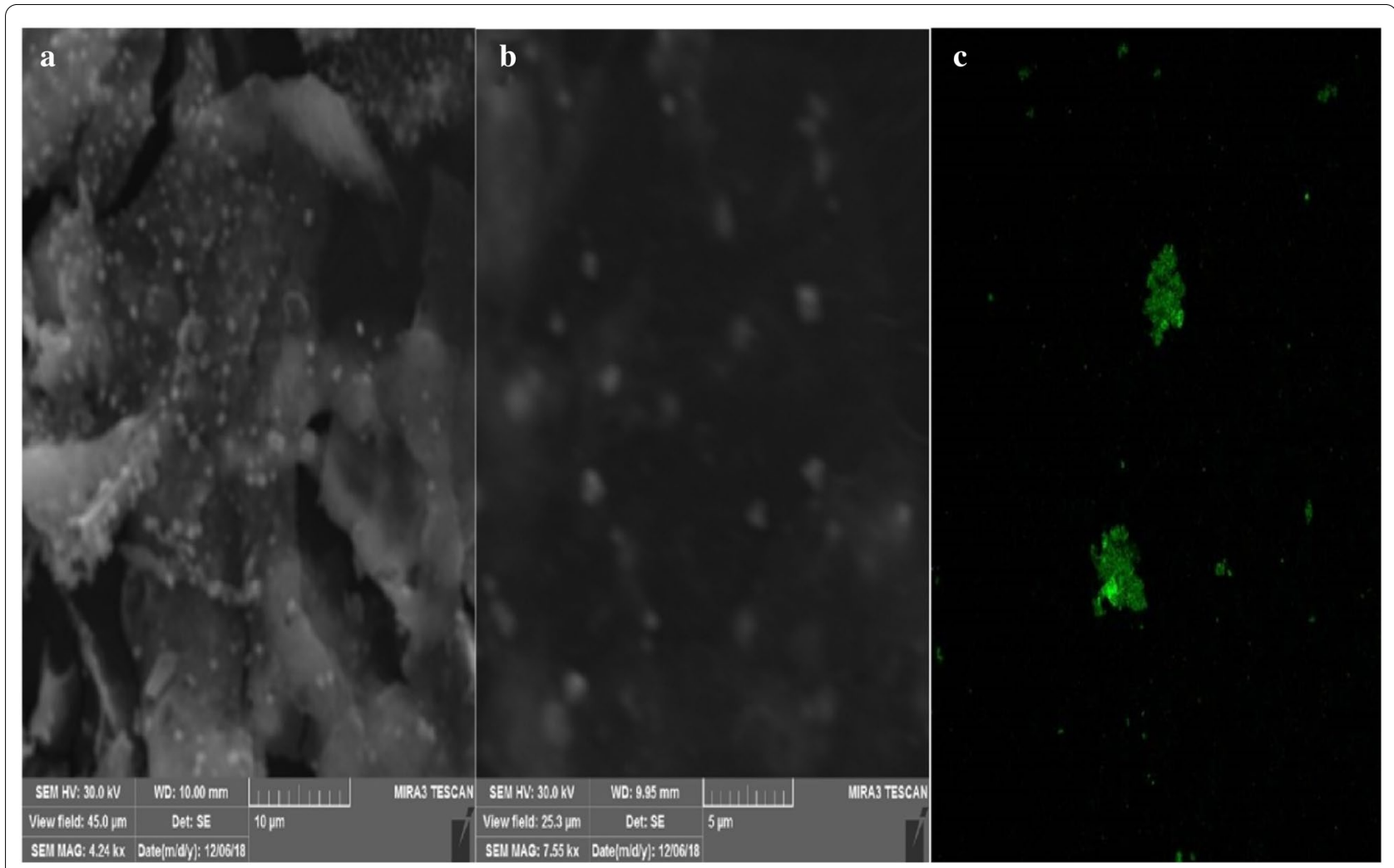

Fig. 5 SEM (a, b) and confocal (c) images of the SNP synthesized from Leea coccinea leaf extract 

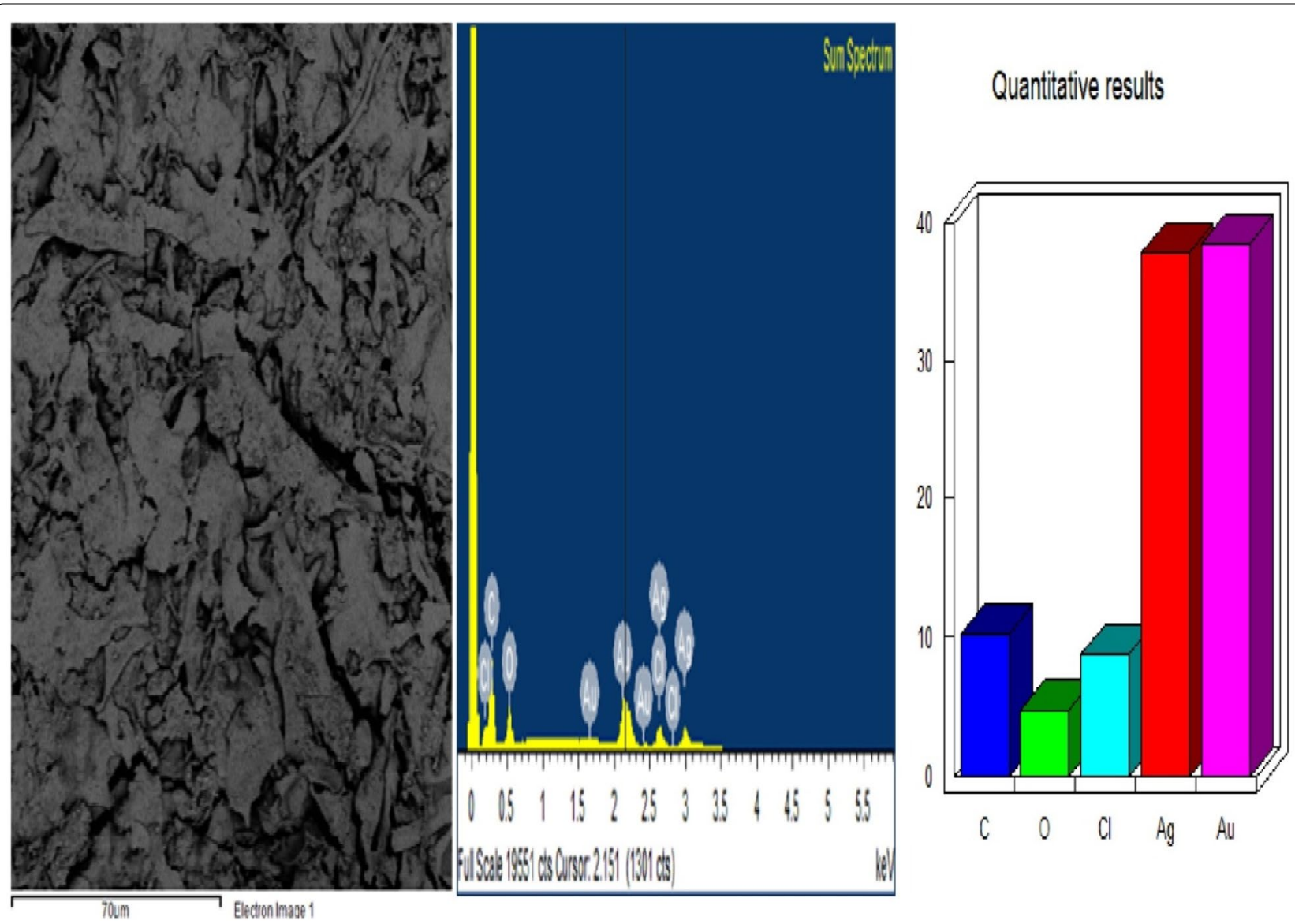

Fig. 6 EDX of the SNP synthesized by Leea coccinea leaf extract

genus (Lakornwong et al. 2014). Chemical studies of Leea indica reported six phenolic compounds, flavan3-ols, flavonoids/flavonoid glycosides, dihydrochalcones and dimeric catechins (Singh et al. 2019). Similar studies based on NMR, MS, and ECD spectra reported one new lignan, one new lactam, five known lignans, four flavonoid glycosides, among other compounds isolated from the ethanol extracts of the aerial parts of Leea aequata (Tun et al. 2019).

SNP showed a promising activity against the tested Gram-negative bacterial strain of $X$. phaseoli pv phaseoli (Fig. 7, Table 2). In previous studies where the activity of AgNPs synthesized from the residual extract of the hydrodistillation of the essential oil of Thymus vulgaris was evaluated, similar activity against this bacterium (Travieso et al. 2018) was demonstrated. However, in the present study, in which the precipitated NPs were evaluated, little diffusion of these nanostructures was found, so biological evaluation studies must be completed with the addition of stabilizing agents. On the other hand, the antimicrobial activity of AgNPs depends on parameters such as $\mathrm{Ag}$ concentration, as well as on the size and shape of the nanostructures (Duval et al. 2019). However, other parameters have recently been shown to influence antibacterial activity such as stabilization in the aqueous medium and the accessibility of the surface of bacteria cell by NPs (Duval et al. 2019).

Formation of aggregates and agglomerates are the main destabilizing factor. They reduce the accessible surface area in contact with the bacterial cell and also inhibit the diffusion capacity in the in vitro tests (diffusion in agar), interfering with the results. The diffusion coefficients of the silver nanoparticles are generally related to size and physico-chemical characteristics (Xiaoxue et al. 2020). For this reason, diffusion methods are used in initial or screening studies; however, they are not valid for the determination of minimum inhibitory concentrations (MIC) and minimum bactericidal concentrations $(\mathrm{MBC})$, suggesting tests such as serial dilutions in which, in addition, the liquid medium facilitates the interaction of the substances to be evaluated with the microorganism through agitation.

Limitations of the antimicrobial activity studies of AgNPs have been pointed out by some authors, 
Table 1 Phytochemical screening of the aqueous extracts of Leea coccinea leaves

\begin{tabular}{|c|c|c|c|c|}
\hline No. & Phytochemical & Test & Result & Qualitative reaction \\
\hline 1 & Flavonoids & Shinode & + & \\
\hline 2 & Triterpenes and steroids & Liebermann-Burchard & + & \\
\hline 3 & Saponins & Froth & - & - \\
\hline 4 & Alkaloids & $\begin{array}{l}\text { Mayer }(M) \\
\text { Dragendorff (D) } \\
\text { Hager }(H) \\
\text { Wagner }(W)\end{array}$ & $\begin{array}{l}- \\
- \\
- \\
-\end{array}$ & \\
\hline 5 & Phenols & $\begin{array}{l}\text { Ferric chloride } \\
\text { Gelatin }\end{array}$ & $\begin{array}{l}+ \\
+\end{array}$ & \\
\hline 6 & Lactonic rings & Kedde & - & \\
\hline 7 & Free amino acids & Ninhydrin & + & \\
\hline 8 & Leucoanthocyanidins & Rosenheim & + & \\
\hline 9 & Quinones & Borntrager & - & \\
\hline
\end{tabular}

- absent; + present

suggesting, among other standardized ones, those methods with a liquid medium (macrodilution and microdilution), the Kirby-Bauer method, prior knowledge of the diffusion coefficient of the sample.

\section{Conclusions}

The present research reports, for first time, the biosynthesis of fluorescent silver nanoparticles from aqueous extract of $L$. coccinea fresh leaves through of a simple, fast, economically feasible and environmentally safe route. SNP formation was confirmed visual and spectroscopically (UV-VIS and FTIR spectrum), and its high degree of agglomeration and fluorescence were visualized by the microscopic techniques used. Several functional groups characteristic of flavonoids, phenols, leucoanthocyanidins, terpenes and steroids with reducing properties could be involved in the cationic bio-reduction. The antibacterial activity against $X$. phaseoli pv phaseoli of the purified SNP was demonstrated by a zone of inhibition of the microbial growing. Sustainable use of this natural resource constitutes an advantageous alternative for this purpose. Future research should be directed to chemical, biological and pharmaceutical studies for the future design of stable, effective and safe formulations for plant protection. 

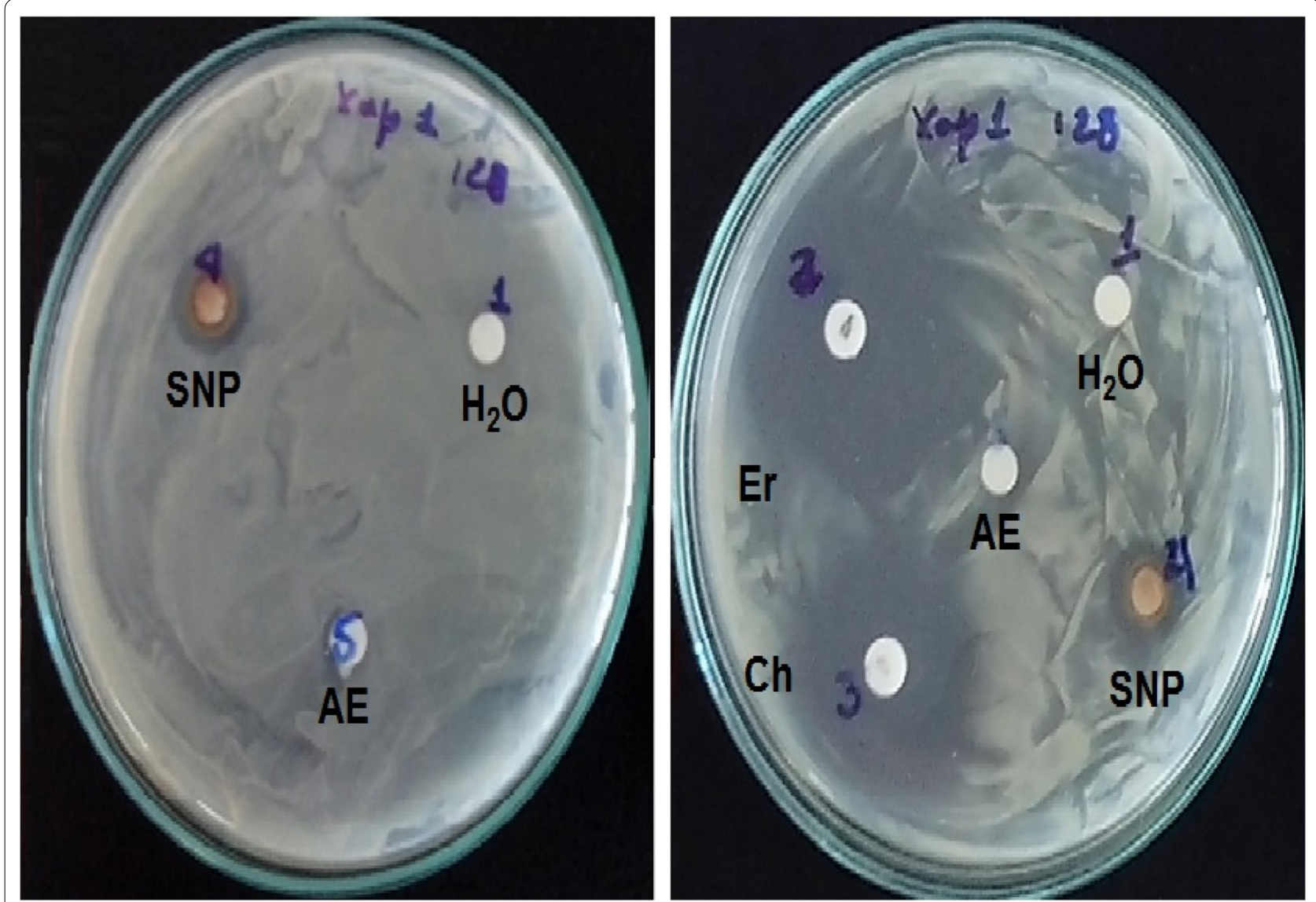

Fig. 7 Antibacterial activity of SNP from Leea coccinea leaves against Xanthomonas phaseoli pv phaseoli. SNP: silver nanoparticles; $\mathrm{H}_{2} \mathrm{O}$ : sterile water; Er: erythromycin; Ch: chloramphenicol; AE: aqueous extract of fresh leaves of L. coccinea

\begin{tabular}{|c|c|c|c|}
\hline Number & Sample & $n$ & Zone of inhibition $(\mathrm{mm})$ \\
\hline 1 & Sterile water $\left(\mathrm{H}_{2} \mathrm{O}\right)$ & 8 & $\mathrm{NI}$ \\
\hline 2 & Erythromycin (Er) & 4 & $33,00 \pm 1,41 a$ \\
\hline 3 & Chloramphenicol (Ch) & 4 & $29,00 \pm 1,41 b$ \\
\hline 4 & SNP & 8 & $12,00 \pm 0,00 c$ \\
\hline 5 & Aqueous extract (AE) & 4 & $\mathrm{NI}$ \\
\hline
\end{tabular}

Values $\pm S D$ indicates the replicates of the experiment $(n)$

\section{Abbreviations}

SNP: Silver nanoparticles; masl: Meters above sea level; FTIR: Fourier transform infrared spectroscopy; UV-VIS: Ultraviolet-visible; nm: Nanometer; NP: Nanoparticle; MNP: Metallic nanoparticle; WN: Weight/volume; SEM: Scanning electron microscopy; EDX: Energy dispersive X-ray; NMR: Nuclear magnetic resonance; MS: Mass spectrometry; ECD: Electronic circular dichroism.

\section{Acknowledgments}

The authors wish to acknowledge the Center of Advanced Studies of Cuba (CEA) for providing research facilities to the characterization studies. Also, the National Program of Nanoscience of Nanotechnology from Cuba for providing financial support to make possible this research. Technical support of technicians Cecil González (from CENSA) and Dania Mora, Ananayla Vizcaino and Ahmed Valdes (from CEA) were indispensable to successful ending of the study.

\section{Authors' contributions}

AR designed and performed the experiments, microbiological assays, statistical analysis, prepared figures and/or tables, authored or reviewed drafts of the paper. BA performed the experiments, prepared figures and/or tables. MC designed and performed the microbiological experiments. LD as associated student of the project performed the experiments of phytochemical screening, analyzed the data, contributed, prepared figures and/or tables. EA performed the experiments of characterization of the nanoparticles, analyzed the confocal data, prepared photos. OP designed and supervised the experiments, analyzed the data, significant opportunities and applications of nanotechnology in plant protection. MCT designed and performed the experiments, processing of primary data, interpretation and integration of results, and written the document. All authors read and approved the final manuscript.

\section{Funding}

These results were supported by National Program of Nanoscience and Nanotechnology of Ministry of Science and Environmental from Cuba.

\section{Availability of data and materials}

All data generated or analyzed during this study are included in this article.

\section{Ethics approval and consent to participate}

All authors have read and agreed to the ethics for publishing the manuscript. 


\section{Consent for publication}

All authors approved the consent for publishing the manuscript to the Journal of Bioresources and Bioprocessing.

\section{Competing interest}

There are no conflicts of interest to be declared.

\section{Author details}

${ }^{1}$ Laboratory of Chemical-Ecology, National Center for Animal and Plant Health (CENSA), San José de las Lajas, Mayabeque, Cuba. ${ }^{2}$ Laboratory of Plant Bacteriology, National Center for Animal and Plant Health (CENSA), San José de las Lajas, Mayabeque, Cuba. ${ }^{3}$ Center of Advanced Studies of Cuba (CEA), La Habana, Cuba.

Received: 1 October 2020 Accepted: 4 December 2020

Published online: 04 January 2021

\section{References}

Pedroza AS, Trejo RC, Chávez RJA (2013) Tolerance to water and plant stress through agronomic and physiological indicators in different bean (Phaseolus vulgaris L.). Rev Mex Fitopatol 31(2):91-104

Corzo M, Rivero G D, Martínez ZY, Martínez B (2015) Detección e identificación de nuevos aislados de Xanthomonas axonopodis pv. phaseoli en cultivares de frijol común. Rev Prot Veg 30(2):97-103

Constantin EC, Cleenwerck I, Maes M, Baeyen S, Malderghem CV, De Vos P, Cottyn B (2016) Genetic characterization of strains named as Xanthomonas axonopodis pv. dieffenbachiae leads to a taxonomic revision of the $X$. axonopodis species complex. Plant Pathol 65(5):792-806

Francisco FN, Gallegos MG, Ochoa FYM, Hernández CFD, Benavides MA, Castillo RF (2013) Aspectos fundamentales del tizón común bacteriano (Xanthomonas axonopodis pv. phaseoli Smith): Características, patogenicidad y control. Rev Mex Fitopatol 31(2):147-160

Rodríguez OM, Faure BA, Ortiz RP, Miranda SL, Lamz AP (2015) Answer to common bacterial blight (Xanthomonas axonopodis pv. phaseoli) in the commercial cultivars of common bean of Cuba, under field conditions. Affectation of the yields for effect of the inoculation. Cult Trop 36(2):92-99

Aguilar JOR, Gallegos GM, Hernández FDC, Cepeda MS, Sánchez DA (2019) Incidencia y severidad del tizón común en plantas de frijol inoculados con Rhizobium phaseoli. Rev Mex Cienc Agr 10(2):325-336

Ararsa L, Fikre L, Getachew A (2018) Evaluation of integrated management of common bacterial blight of common bean in Central Rift Valley of Ethiopia. Am J of Phytomed and Clin Therap 6(1):3. https://doi.org/10.21767 /2321-2748.100339

Ram JL, Osdaghi E, Behlau F, Köhl J, Jones JB, Aubertot JN (2018) Thirteen decades of antimicrobial copper compounds applied in agriculture. A review. Agron Sust Dev 38(3):28. https://doi.org/10.1007/s13593-018-0503-9

Rajesh S, Raja DP, Rathi JM, Sahayaraj K (2012) Biosynthesis of silver nanoparticles using UIva fasciata (Delile) ethyl acetate extract and its activity against Xanthomonas campestri pv. malvacearum. J Biopest 5:119-128

Shende SS, Gaikwad ND, Bansod SD (2016) Synthesis and evaluation of antimicrobial potential of copper nanoparticle against agriculturally important phytopathogens. Int J Biol Res 1(4):41-47

De Luca V, Salim V, Atsumi SM, Yu F (2012) Mining the biodiversity of plants: a revolution in the making. Science 336:1658-1661. https://doi. org/10.1126/science. 1217410

Palhares RM, Gonçalves DM, Dos Santos AF, Pereira CG, Das Graças LB, Oliveira G (2015) Medicinal plants recommended by the world health organization: DNA barcode identification associated with chemical analyses guarantees their quality. PLoS ONE 10(5):e0127866. https://doi.org/10.1371/ journal.pone.0127866

NewmanDJ CraggGM (2016) Natural Products as Sources of New Drugs from 1981 to 2014. Review J Nat Prod 79(3):629-661. https://doi.org/10.1021/ acs.jnatprod.5b01055

Rai M, Yadav A, Gade A (2009) Silver nanoparticles as a new generation of antimicrobials. Biotechnol Adv 27(1):76-83. https://doi.org/10.1016/j. biotechadv.2008.09.002

Kasithevar M, Saravanan M, Prakash P, Kumar H, Ovais M, Barabadi H et al (2017) Green synthesis of silver nanoparticles using Alysicarpus monilifer leaf extract and its antibacterial activity against MRSA and CoNS isolates in HIV patients. J Interdisc Nanomed 2(2):131-141. https://doi. org/10.1002/jin2.26

Rao H, Lakshmidevi N, Pammi SV, Pratap K, Ganapaty S, Lakshmi P (2016) Green synthesis of silver nanoparticles using methanolic root extracts of Diospyros paniculata and their antimicrobial activities. Mater Sci Eng, C 62:553-557. https://doi.org/10.1016/j.msec.2016.01.072

Sarkar D, Goutam P (2017) Green synthesis of silver nanoparticles using Mentha asiatica(mint) extract and evaluation of their antimicrobial potential. Int J Curr Res Biosci Plant Biol 4(1):77-82. https://doi.org/10.20546/ijcrb p.2017.401.009

Arokiyaraj S, Vincent S, Saravanan M, Lee Y, Oh YK, Kim KH (2017) Green synthesis of silver nanoparticles using Rheum palmatum root extract and their antibacterial activity against Staphylococcus aureus and Pseudomonas aeruginosa. Artif Cells Nanomed Biotechnol 45:372-379

Singh K, Panghal M, Kadyan S, Chaudhary U, Yadav JP (2014) Green silver nanoparticles of Phyllanthus amarus: as an antibacterial agent against multi drug resistant clinical isolates of Pseudomonas aeruginosa. J Nanobiotech $12: 40$

Sun Q, Cai X, Li J, Zheng M, Chen Z, Yu C (2014) Green synthesis of silver nanoparticles using tea leaf extract and evaluation of their stability and antibacterial activity. Colloids Surf A Physicochem Eng Asp 444:226-231

Rajathi K, Sridhar S (2013) Green synthesized silver nanoparticles from the medicinal plant Wrightia tinctoria and its antimicrobial potential. Int J Chem Tech Res 5(4):1707-1713

Chandrappa C, Chandrasekar N, Govindappa M, Shanbhag C, Kumar U, Masarghal J (2017) Antibacterial activity of synthesized silver nanoparticles by Simaroubaglauca against pathogenic bacteria. Int J Curr Pharm Res 9(4):19-22

Ronavari A, Kovacs D, Igaz N, Vagvolgyi C, Miklos I et al (2017) Biological activity of green synthesized silver nanoparticles depends on the applied natural extracts: a comprehensive study. Int J Nanomed 12:871-883

Sharma D, Ledwani L, Bhatnagar N (2015) Antimicrobial and cytotoxic potential of silver nanoparticles synthesized using Rheum emodi roots extract. Ann West Univ Timisoara 24(2):121-135

Dhand V, Soumya L, Bharadwaj S, Chakra S, Bhatt D, Sreedhar B (2016) Green synthesis of silver nanoparticles using Coffea arabica seed extract and its antibacterial activity. Mater Sci Eng C Mater Biol Appl 58:36-43

Suparna R, Anantharaman P (2017) Biosynthesis of Silver Nanoparticles by Chaetomorpha antennina (Boryde Saint-Vincent) Kutzing with Its Antibacterial Activity and Ecological Implication. J Nanomed Nanotechnol 8(5):467. https://doi.org/10.4172/2157-7439.1000467

Kumar R, Ghoshal G, Jain A, Goyal M (2017) Rapid Green Synthesis of Silver Nanoparticles (AgNPs) Using (Prunus persica) Plants extract: Exploring its Antimicrobial and Catalytic Activities. J Nanomed Nanotechnol 8:452. https://doi.org/10.4172/2157-7439.1000452

Ibraheem IBM, Abd Elaziz BEE, Saad WF, Fathy WA (2016) Green biosynthesis of silver nanoparticles using marine red algae Acanthophora specifera and its antimicrobial activity. J Nanomed Nanotechnol 7:409. https://doi. org/10.4172/2157-7439.1000409

Anandalakshmi K, Venugobal J (2017) Green synthesis and characterization of silver nanoparticles using Vitex negundo (Karu Nochchi) leaf extract and its antibacterial activity. Med Chem 7:218-225. https://doi. org/10.4172/2161-0444.1000460

Algebaly AS, Mohammed AE, Abutaha N, Elobeid MM (2020) Biogenic synthesis of silver nanoparticles: antibacterial and cytotoxic potential. Saudi J Biol Sci 27:1340-1351. https://doi.org/10.1016/j.sjbs.2019.12.014

Travieso MC, Rubio A, Corzo M, Pino O (2018) Silver nanoparticles obtained from the residual extract of the hydro distillation of Thymus vulgaris $L$. and its effect on Xanthomonas phaseoli pv. phaseoli. Rev Prot Veg 33(3):3

Gupta D, Chauhan P (2017) Green synthesis of silver nanoparticles involving extract of plants of different taxonomic groups. J Nanomed Res 5(2):00110. https://doi.org/10.15406/jnmr.2017.05.00110

International Seed Testing Association (2013) Document OGM13-05A Proposed changes to the ISTA List of Stabilized Plant Names p. 7/13

Emran TB, Rahman MA, Hosen SMZ, Rahman MM, Toufiqul AM, Chowdhury MAU, Uddin ME (2012) Analgesic activity of Leea indica (Burm. F.) Merr. Phytopharmacol 3(1):150-157

Joshi A, Prasad SK, Kumar VJ, Hemalatha S (2016) Phytochemical standardization, antioxidant, and antibacterial evaluations of Leea macrophylla: a wild edible plant. J Food Drug Anal 24:324-331. https://doi.org/10.1016/j. jfda.2015.10.010 
Mahmud ZA, Bachar SC, Hasan CM, Emran TB, Qais N, Nasir MU (2017) Phytochemical investigations and antioxidant potential of roots of Leea macrophylla (Roxb.). BMC Res Not 10:245. https://doi.org/10.1186/s1310 4-017-2503-2

Halder S, Saqueeb N, Qais N (2018) Antinociceptive and anthelmintic activities of leaves of Leea aequata. Dhaka Univ J Pharm Sci 17(2):251-255. https:// doi.org/10.3329/dujps.v17i2.39183

Tun NL, Hu DB, Xia MY, Zhang DD, Yang J, Naing TO, Wang YH, Yang XF (2019) Chemical constituents from ethanoic extracts of the aerial parts of Leea aequata L., a traditional folk medicine of Myanmar. Nat Prod and Bioprosp 9:243-249. https://doi.org/10.1007/s13659-019-0209-y

Clinical and Laboratory Standars Institute (CLSI) (2015) Performance Standards for Antimicrobial Disk Susceptibility Test Approved Standard. Ed 12. 35(1):15

Di Rienzo JA, Casanoves F, Balzarini MG, Gonzalez L, Tablada M, Robledo CW. InfoStat versión 2016. Grupo InfoStat, FCA, Universidad Nacional de Córdoba, Argentina. http://www.infostat.com.ar

Vadlapudi V, Amanchy R (2017) Synthesis, characterization and antibacterial activity of silver nanoparticles from red algae Hypnea musciformis. Adv Biol Res 11(5):242-249. https://doi.org/10.5829/idosi.abr.2017.242.249

Khan MZH, Tareq FK, Hossen MA, Roki AM (2018) Green synthesis and characterization of silver nanoparticles using Coriandrum sativum leaf extract. J Eng Sci and Tech 13(1):158-166

Zuorro A, Llannone A, Natali S and Lavecchia R, (2019) Green synthesis of silver nanoparticles using bilberry and red currant waste extracts. Proc 7:193. https://doi.org/10.3390/pr7040193

Jeevanandam J, Chan YS, Danquah MK (2016) Biosynthesis of metal and metal oxide nanoparticles. Chem Bio Eng Rev 3(2):55-67

Lakornwong W, Kanokmedhakul K, Kanokmedhakul S (2014) Chemical constituents from the roots of Leea thorelii Gagnep. Nat Prod Res 28(13):1015-1017. https://doi.org/10.1080/14786419.2014.891117

Singh D, Siew YY, Chong TI, Yew HC, Ho SS, Lim CS, Tan WX, Neo SY, Koh HL (2019) Identification of phytoconstituents in Leea indica Burm. F.) Merr. leaves by high performance liquid chromatography micro time-of-flight mass spectrometry. Molecules 24:714. https://doi.org/10.3390/molec ules 24040714

Talamond P, Verdeil JL, Conéjéro G (2015) Secondary metabolite localization by autofluorescence in living plant cells. Molecules 20:5024-5037

Donaldson L, Williams N (2018) Imaging and spectroscopy of natural fluorophores in pine needles. Plants 7:10. https://doi.org/10.3390/plants7010 010

Singh C, Kumar J, Kumar P, Singh B, Tiwari KN, Mishra SK et al (2019b) Green synthesis of silver nanoparticles using aqueous leaf extract of Premna integrifolia (L.) rich in polyphenols and evaluation of their antioxidant, antibacterial and cytotoxic activity. Biotech Biotech 33(1):359-371

Moodley JS, Babu S, Krishna N, Pillay K, Govender P (2018) Green synthesis of silver nanoparticles from Moringa oleifera leaf extracts and its antimicrobial potential. Adv Nat Sci 9:1-9. https://doi.org/10.1088/2043-6254/ aaabb2

Oluwasogo A, Amoo AF, Fehintoluwa E, Adelani AAT, Oluwasesan M, Rita C et al (2019) Silver nanoparticle synthesis by Acalypha wilkesiana extract: phytochemical screening, characterization, influence of operational parameters, and preliminary antibacterial testing. Heliyon 5:1-8. https:// doi.org/10.1016/j.heliyon.2019.e02517

Duval RE, Gouyau J, Lamouroux E (2019) Limitations of recent studies dealing with the antibacterial properties of silver nanoparticles: fact and opinion. Nanomat 9(1775):1-22. https://doi.org/10.3390/nano9121775

Xiaoxue IY, Zhang J, Shuping IZ, Lei MM, Li Q, Hung CC (2020) The antibacterial mechanism of silver nanoparticles and its application in dentistry. Int J Nanomed 15:2555-2562. https://doi.org/10.2147/IJN.S246764

\section{Publisher's Note}

Springer Nature remains neutral with regard to jurisdictional claims in published maps and institutional affiliations.

\section{Submit your manuscript to a SpringerOpen ${ }^{\odot}$ journal and benefit from:}

- Convenient online submission

- Rigorous peer review

- Open access: articles freely available online

- High visibility within the field

- Retaining the copyright to your article

Submit your next manuscript at $\boldsymbol{\nabla}$ springeropen.com 